\title{
Warmumformung verzinkter Stähle
}

Karl M. Radlmayr, R. Kelsch, A. Sommer, T. Kurz, J. Faderl, voestalpine Metal Forming $\mathrm{GmbH}$, Österreich

Zum Zeitpunkt der Drucklegung lagen diese Unterlagen noch nicht vor. Wir bitten um Verständnis. 